\title{
Planning and Development Confront in Climate Change Context
}

Bharat Gotame ${ }^{1}$

\begin{abstract}
There are ample of evidences to prove the impacts of Climate Change and will be with us for a long time to come. It will have significant impact on natural systems so that most of the habitat of living organism is directly influenced moreover the human being (which is heterotrophic in nature) and their roles to sustain the development and earth at summary are being vulnerable. This literature review article tries to summarize some climate change scenario and its increasing impact over the livelihood assets and their direct/indirect influence to development fronts. Nepal a developing country having more than $70 \%$ of mountainous regions with agriculture based economy is more susceptible to climate change impacts. Planning of development activities remarked with increasing trend of climate change impact with pivotal theme should make the development more sustainable and long living. Existing initiatives to make adaptation options are insufficient to halt the expected danger and redesigning the module of development is urgent in Nepal. On adaptation and vulnerability, a continuing effort must take place to exchange experiences and look for emerging best practices and frameworks. The urgency of the issue requires planners, policy makers, evaluators, practitioners and researchers to become involved in designing and in empowering communities and government as well.

हामीसँग अहिले जलवायु परिवर्तनका असर धेरै नै छन् र परिरहने छन् भन्ने कुराको प्रमाणहरु छन्। जसका उल्लेख्य प्रभाव प्राकृतिक स्रोत अनि प्रकृतिमा रहेका जीवजन्तुहरुको वासस्थान र मानिस स्वयंमा पर्ने हुनाले पृथ्वीका स्रोत तथा साधनहरुको दिगो उपयोग तथा विकासमा खतरा उत्पन्न भईरहेको छ। यस लेखले समेट्न खोजेको पक्ष चाहिं विद्यमान जलवायु परिवर्तनको रुप तथा यसका बढ़दो प्रभावले प्रत्यक्ष अप्रत्यक्ष रुपमा जिविकोपार्जन र विकासका गतिमा पारेको असर हो। नेपाल विकासोन्मुख तथा $७ ०$ प्रतिशत भन्दा बढि हिमाली भू-भागले वनेको मुलुक हो जहाँको अर्थतन्त्र कृषिमा आधारित छ। त्यसैले गर्दा नेपाल जलवायु परिवर्तनका पृष्ठभूमिमा संकटउन्मुख देशमा पर्दछ। जिविकोपार्जनको दिगो उपाय अपनाउन विकासका योजनाहरु तय गर्दा अव जलवायु परिवर्तन र यसका भावि प्रभावहरुलाई मध्यनजर गर्नुपर्ने हुन्छ। हाल भईरहेका अनुकुलताका उपायहरु संकट समाधानार्थ अपर्याप्त छन्। त्यसैले विकासका कार्यक्रमहरु बदलिदो परिवर्तनलाई मध्यनजर गर्दे प्राप्त अनुभव र उत्कृष्ट कार्यहरुको आधारमा तय गर्नको लागि योजनाविद्, नीतिनिर्माताहरु, अनुसन्धानकर्ताहरु कार्यान्वयन तथा मुल्यांकनकर्ताहरुको विवेकशिल सहभागिता समुदाय तथा सरकारी स्तरमा गरिनु जरुरी देखिन्छ।
\end{abstract}

Key Words: Climate change, Development, Planning, Economic impact, Adaptation

\section{Introduction}

Climate change is the phenomenon of changes in the earth's climate due to human induced causes to the natural systems of the earth. Almost every day, we can find more and more evidences that the earth's climate is changing. Scientists have predicted that the global mean temperature in 2100 might increase by $2^{\circ} \mathrm{C}$ from that of $1990^{*}$. The 1990 s was the warmest

\footnotetext{
${ }^{1}$ Kathmandu Forestry College, Kathmandu, Nepal, Email: bgotame@gmail.com

"Assuming best estimate value of climate sensitivity $2^{\circ} \mathrm{C}$. The result is obtained from the non-intervention scenario, IS92a, of Second Assessment report of Intergovernmental Panel on Climate Change, 1995.
} 
decade in the last hundred years, and 1998 was the warmest year on record. During the past century, global temperatures had climbed by about $0.5^{\circ} \mathrm{C}$-the largest increase in at least one thousand years. Nepal, a mountainous country, having high altitudinal range should ultimately bear the higher impact of climate change. Temperature fluctuation (generally increases from south to north and is accompanied by decreasing temperatures) trend is generally warming with remarkable greater warming at higher elevations than lower elevations ${ }^{2}$. Recently Nepali national daily reported that rainfall variation occurred due to causes of climate change ${ }^{3}$. Change in precipitation time and period, the movement of wind (cyclones) and glacier retreat seem major events as an evidence of continuous changing of climate. The more the Green House Gases $(\mathrm{GHG})^{4}$ releases to the atmosphere the more influences occur in the climate.

There are lots of arguments from economists, planner and development activists about the climate change regarding the outcome of this environmental change like Josheph E. Stiglitg expressed his views in his book "Making Globalization Work" "The world is currently engaged in a grand experiment, studying what happens when you release carbon dioxide and certain other gases into the atmosphere in larger and larger amounts". The emission of carbon dioxide is largely acclaimed by human activities that we mostly say development. Development is a positive change towards the welfare of human beings and it should be beneficial for forthcoming generation too. The time being has enforced to transform the course of development agendas in this era. Welfare approach could not address the new coming issues of development where people are searching their right as their increasing level of consensus. Now climate change has been viewed largely as a development relevant issue not only as an environmental agenda. Planners, development policy makers or practitioners all should be equally involved in climate change issues so that they could design the best model of development which could be sustainable in the changing scenario.

\section{Change in environment and development discourse}

The current discourse on climate change partially evoked to international concern is not yet be materialized as transforming factor to modify the development approaches. Based on evidences, climate change brings frontiers to reassess the priorities and performances on agricultural subsidy/loan, natural resource management programs and activities, infrastructure development, international affair on import and export, power generation and energy supplement programs. The direct and indirect impacts of such priorities shifting call for more initiatives at national and international regime. Land degradation simply looks as an environmental problem especially in developing countries but there are extra connectives to enlist the induced problems and shift the program priorities in all sectors of planning. Land

\footnotetext{
${ }^{2}$ Source: MOPE and UNEP (2004)

${ }^{3}$ The Katmandu Post daily, Sep 2008, Page 1,

${ }^{4}$ Green house gases are Carbon dioxide, Methane, Nitrous oxide, Ozone and Halocarbons which are occur in the atmosphere.
} 
degradation not only brings the issues of productivity decrease, food scarcity increase and disturbance in the social harmony (due to poverty/hunger) but also disturbs the indirect association of land use like tourist flow and water source/amount decrease.

As the emissions scenario demarcate the two development context spatially and temporally due to the shift in priority i.e. subsistence economy in developing countries and developed countries since the $80 \mathrm{~s}$ decade. Policy outlooks are changing in national and international arena. United Nations organizations and other multilateral/bilateral organizations put the priority to climate change; moreover the urgency should be life of vulnerable people who are in demand of substantial solution to adopt in climate change context.

Fig 1: Climate change and development link

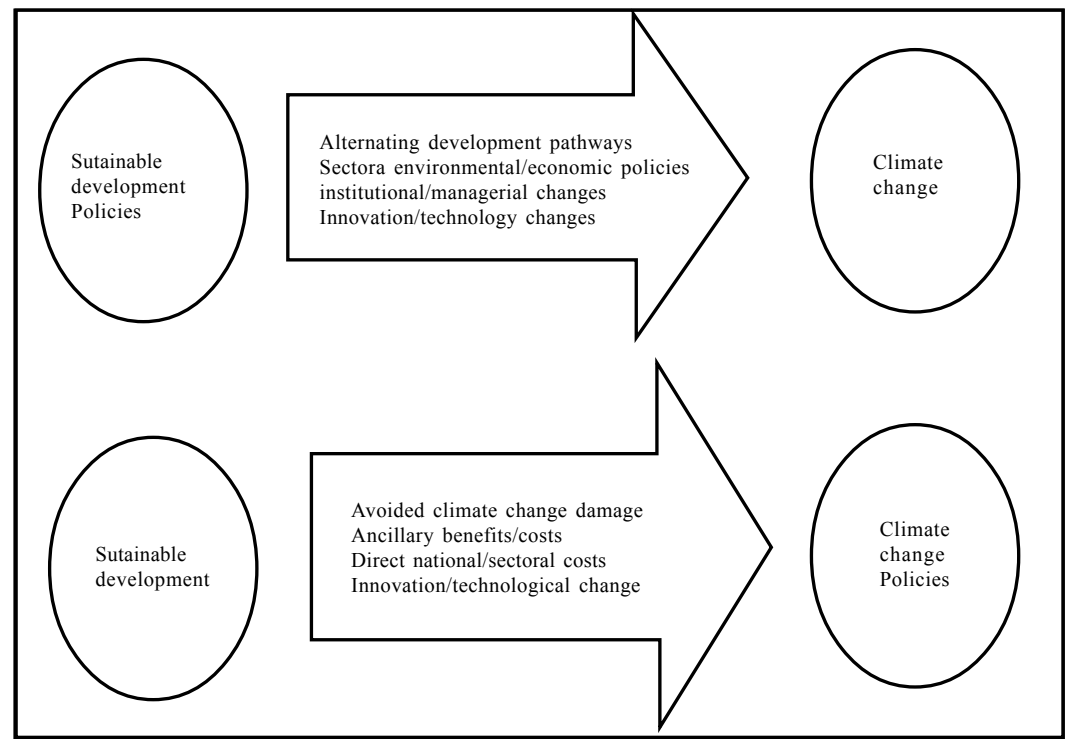

Source: Swert et al 2003, adopted from Huq 2006

Very few steps are moved to identify the contemporary changes/projections and its future consequences to locate the actual people and their livelihood assets in the adaptation plan. So Benefit-cost analysis and the cost effectiveness assessment are urgently needed to invite the potential victims and advocate accordingly as a partial solution to support these. Among the different types of capital assets, natural assets is most important than human, financial, physical social assets to support their livelihood especially for forest dependent people. If we can't consider the temperature change trend and projection, we may forward to disharmonies livelihood of millions of people who are living near the sea shore. The indirect associations of this changes upload the various threats to hundreds of thousand human settlements who are living far from seashore especially mountain people should face great tragedy due to changes. 


\section{Planning for sustainable development}

Planning techniques and practices have been central to development since its inception (Escobar). Lots of approaches have been practiced as a planning tool. The major concern is the targeted beneficiaries should get the output or not after plan implementation. There is one argument about planning that planning is deeply rooted in human psychology. The most concern nowadays is sustainable development. Rio summit 1992 brought clear roadmap of sustainable development, then Johanesborg summit 2002 have made concrete plan to establish the bench mark as a best notation for all developing and developed countries. The loser and winner both were ready to demarcate the boundary line to sustain the living environment. Kyoto Protocol 1997 ( a first international agreement, which legally binds, developed nation to reduce worldwide emissions of GHG from these countries) was made as a key step towards the mitigation of climate change due to increased greenhouse gases accumulation in atmosphere. After realizing the fact that $20 \% \mathrm{GHG}$ emissions come from deforestation and degradation, 13th Conference of the Parties (COP) to the United Nations Framework Convention on Climate Change (UNFCCC) in Bali in 2007 has recognized REDD as a potential climate change mitigation option. The promotion of green initiatives in the world may be the wise way to sustain millions of livelihoods and ensure the future of living environments.

Microeconomic analysis of environmental goods and services should way out the conflict to answer; why environmental concerns are at the heart of the sustainable development for addressing poverty and promotion of household welfare. Environmental change, particularly of local natural resources, can affect poverty through many pathways (adopted from WB 2008). If a poor household whose welfare depends on biophysical, human, environmental and constructed capital, they

should bear great disaster with the exogenous shock (unexpected changes as a result of natural disasters, death, gifts or macro market changes) in figure2. The convenience of the environmental changes and climate concern should combine the sole responsibility of all multi stakeholders to reassess the development priorities because the welfare of a unit of society symbolizes the economic harmony of that country.

Fig 2: Poverty environment linkages at the household level.

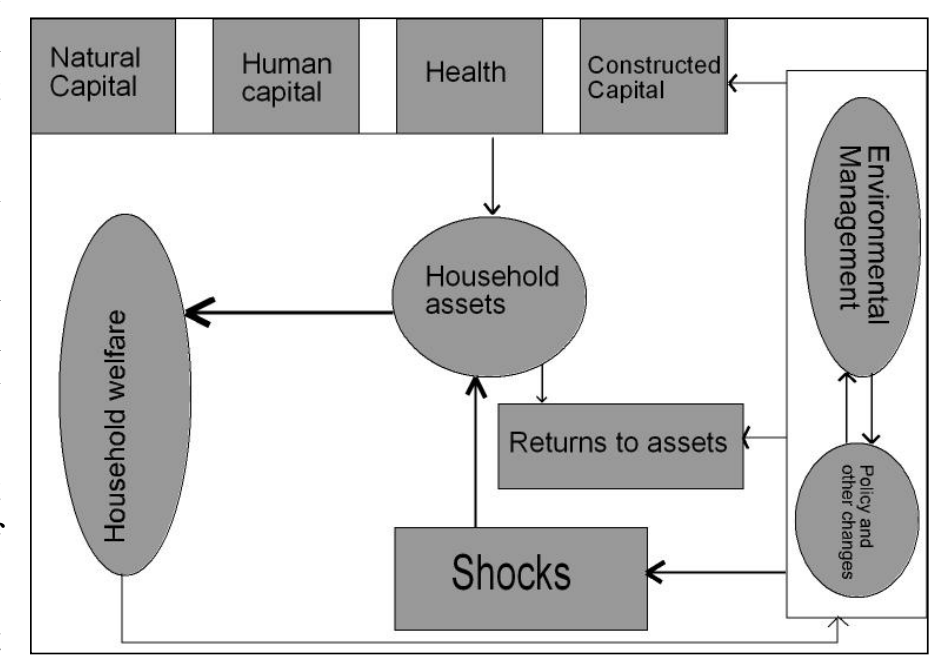

Source: World Bank, 2008 
We have already lots of evidences that climate change have influenced over all these assets. Especially Glacier lake outburst flood in Himalayan countries is major threat to people of mountains and Terai and flash flood is another one to make revisit in the development planning. In summation, climate change impacts are directly connected to household economy and the global economy. The globalization making is for rich or poor, developed or developing countries but responding to the enormous challenges posed by global warming is not harmonious to all.

\section{Nepalese context in development and planning}

After six years of the dawn of democracy in 1950, Nepal's planned development began with the first five year plan in 1956. There were not any initiatives to focus on environmental issues till fifth five year plan (1975-1980) which incorporated some environmental components like emphasis on ecological balance, conservation of national forests and wildlife, reduction of urban pollution, promotion of ecotourism, encouragement of women's participation in environmental activities (ADB/ICIMOD 2006). Especially focused on climate change issues, Nepal's attention came in front with eighth five year plan (1992-1997). The specific and notable achievements during this Plan period included are Establishment of Ministry of Population and Environment (MoPE)**, Enactment of Environment Protection Act (1996) and promulgation of Environment and Protection Regulations (1997). The ninth plan (19972002) and the tenth plan (2002-2007) still were lacking the concrete action plan to address the issue of climate change in development plans, where IPCC 2001 report already warned the global community about the potential impacts of global warming in different aspects of national economy. Although the main objective of the tenth plan is to alleviate poverty by mobilizing optimally the means and resources on the mutual participation of government, local agencies, non-governmental sectors, private sector and civil society to extend economic opportunities and open new ones, there were numerous causes not to breakthrough the mission of achieving economic growth and materializing the sustainable development agendas. Currently operating three years interim plan (2008-2010) puts forward the forestry sector as a means of economic growth with emphasis on international resources gathering opportunities by carbon trade, climate change mitigation and payment of environmental services.

\section{Climate change impacts and potentials to Nepal:}

No confusion, changing climate has brought many changes in average climate of Nepal but number of anecdotal perceptions about it still remains which can only be verified by researches.

** Now MOFE manage into two ministries, Ministry of Health and Population and Ministry of Environment 
The rapid glacier retreat due to increasing temperature ${ }^{5}$, monsoon variations unpredicted high rainfall ( high rainfall at the end of monsoon or very starting of monsoon), cold and hot in winter and summer days, amount and timing of frost and fogs in the sky are observatory events, these are the impacts of climate change in Nepal. Average climate change is above global average due to the cause of all types of climate exposure to Nepal, steep and fragile mountains in topography, nature based livelihoods (agriculture based subsistence and monsoon is a major source of water for crop), awareness and education lacking and poor economic condition. Climate change will inevitably have an impact on air pollution in the country (ICIMOD/ADB 2006). Potential impact of climate change over all human related sectors and over the entirely living organisms could unpredictably lead them to the phase of extinction.

\section{Linking climate change and development}

The link between climate change and development should be obvious because of the wide ranges of sectors directly and indirectly influenced by climate change impacts. Climate change impacts will significantly affect national development, particularly amongst the world's poorest communities. Human induced climate change is the result of increasing $\mathrm{GHG}$ emissions caused by development factors such as economic growth, technology, population and governance. On the other side climate change itself will have a direct impact on development especially climate sensitive activities such as agriculture and indirect consequences on social issues such as poverty and education.

\section{Some examples of projected impacts of simple extreme climate phenomena}

- If temperature increases in rapid race i.e. more hot days and heat waves over nearly all land areas, there will be increased incidence of death and serious illness in older people and urban poor, increased heat stress in livestock and wildlife and increased risk of damage to several crops. In the rural parts of Nepal, existing people livelihood model will be totally functionless and there will search for other occupation to sustain their life in long run.

- More intense precipitation events happening leads to increased flood, landslide, avalanche and mud-slide damage, increased soil erosion and flood run-off, would result in decreased land productivity, decreased food production, increased food scarcity and hunger. If there is no food there would be no development.

\footnotetext{
${ }^{5}$ A study carried out by MOPE and the United Nations Environment Programme (UNEP) for the Initial National Communication to the Conference of the Parties of the United Nations Framework Convention on Climate Change using models (Canadian Climate Change Model ["CCCM"], Geophysical Fluid Dynamics Model ["GFD3]", and regional Climate Model) and their projections showed a projected 2 to $4^{\circ} \mathrm{C}$ rise in average annual temperature over Nepal when $\mathrm{CO}_{2}$ is doubled. The magnitude of temperature rise would be greater in western Nepal than in other regions. According to the CCCM model, winter showed the greatest increase of any season with the highest value in the far-western region $\left(2.4^{\circ} \mathrm{C}\right.$ to $\left.5.4^{\circ} \mathrm{C}\right)$, and for all seasons, the rising gradient was from east to west, whereas in the GFD3 model it was from west to east during pre-monsoon and winter. (ICOMOD/ADB 2006)
} 


\section{Basis for setting development agendas in Nepal}

More than $80 \%$ of Nepalese people are living with subsistence agriculture, $40 \%$ contribution of agriculture sector in Gross Domestic Product is major mark for designing development agendas, and setting goal and planning activities. Where various researches had already forecasted the foremost impact of changing climate is on agriculture, moreover the economically inferior communities living in northern part of country are more vulnerable to changing climate. Especially in the developing countries like Nepal, which have low per capita income and low economic growth which may imply higher marginal utility of income and lower willingness to pay for environmental improvements and amenities. People are mostly engaged in their production factor (land, labor, capital) in the economic activities but production is always up to subsistence level. Such a practice always leads to low productivity and low concern to environmental issues and mostly busy in livelihood aspects. If increasing trend of occurring impact of climate change continues, more percentage of resources should be incurred for basic needs, others sectors would be automatically shaded in case investment.

\section{Need of clear cut initiatives}

As we had discussed in introductory part, climate change issues are out of the regime of environmentalists to cope with its impacts and maintaining the sustainable world for human welfare in long run. Most of issues generated by climate concern should be within the government habitat. Policy influencing, implementing rules and laws to control GHG emission trend and setting up the plans and implementing accordingly are the major concern to government. For the positive support civil society, donor agencies, local communities, development NGOs should play their role to enforce the government mechanism. Manufacturing companies should be environment friendly for producing environment friendly products and consumer's awareness is vital to do so.

\section{Lesson learned}

Climate change is beyond the control of limited people in the World. Impacts are increasing day by day, future projections have shown that, the human life in sea shore and high mountain are being highly vulnerable. The context of climate change brought the large scale boundary to act collectively. Due to underdeveloped economy and low access to the environmental resources in most of developing countries reflect the higher need of concern over the proper management of common property resources. The following results could be summarized on the basis of above discussions.

- Microeconomic analysis of the environmental goods and services and reflect in the possible regime for modification and access assurance. 
- Major champions for the planning dialogues and pushing factor for integrating development activities with the environmental harmony and long run economic development should came into front from all sectors of development.

- Merits and demerits of developmental path changing should assure the positive influence over the overall development of green and other sectors of economy development.

- Modified approaches should adapt to policy hit and changing planning ways from all domains.

- Special economic regions and their stakeholders must concentrate to the upcoming regional issues of climate change so as to replan the investment regions and activities.

\section{Conclusion}

There are ample of convincing evidences that climate change impacts are more concerned to the people of low income and limited habitat for production but the global climate is changing at an unprecedented rate (IPCC, 2001). A large proportion of the observed rise in global temperatures of $0.6^{\circ} \mathrm{C}$ has been attributed to human activities, principally land clearance and fossil fuel burning, which have released large quantities of greenhouse gases into the atmosphere. So, future socio-economic development pathway scenarios closely related with predicted greenhouse gas emissions. The urgent need of current mindset is searching the alternative ways of subsistence and improving the habit for low carbon production.(Normally conclusion doesn't contain reference)

Planning and development discourse in this verge is really burning to enforce the policy maker and planner for proactive initiatives to plan the environmentally sound project. The global economies (mostly developed countries) are now facing financial recession and most developing countries are directly affected by them. The most vulnerability of people of mountainous countries especially Nepal lies on the uncertainty of climate phenomena, where most production and protection attribute of human life are entirely depend on the climate condition. The need of urgency in development discourse in this context is reflected by the decisions of global forum like G8 summit, UN conventions, probably the most powerful economics of US president's guanine concern over the climate change during his rule.

\section{Reference}

Escobar A. Planning, The Development Dictionary. Sachs W. (ed)

Huq, Saleemul, Reid Hannah, and Murray, L. A. 2006. Climate change and

Developmental Links. International Institute for Environment and Development.

ICIMOD/ADB, Environment Assessment of Nepal- Emerging Issues and Challenges, 2006

IPCC 2001. International Panel on Climate Change, from www.google.com/IPCC TAR 
Mullan, K. and Kontoleon. A benefits and Costs of Forest Biodiversity: Economic Theory and Case Study evidence, final report, June 2008. Source: www.google.com/biodiversity economics.

Poverty and the Environment Understanding Linkages at the Household Level 2008. The World Bank.

Regmi, B. R. and Adhikari, A. 2007. Human Development Report 2007/2008 Fighting climate change: Human solidarity in a divided world Human Development Report Office OCCASIONAL PAPER Country Case Study-Nepal .

Stiglitg, J. E. 2006. Making Globalization Work. Allen lane, England

Summary Statement and Conclusions of the International Conference on Evaluating Climate Change and Development, May 12, 2008."Rob D. van den Berg May 12, 2008 Alexandria, Egypt, Bibliotheca Alexandria.

Three Years Interim Plan, 2064/65-2066/67, 2064 B.S. National Planning Commission, Government of Nepal (In Nepali). 